\title{
Optimization of the $\mathrm{SO}_{3}$ content of an Algerian Portland cement: Study on the effect of various amounts of gypsum on cement properties
}

\author{
Siline Mohammed ${ }^{\mathrm{a}, *}$, Omary Safiullah ${ }^{\mathrm{b}}$ \\ a Laboratory of Materials and Mechanic of Structures (LMMS), University of M'sila, Algeria
}

${ }^{\mathrm{b}}$ ICube, UMR CNRS 7357, INSA de Strasbourg, France

\section{H I G H L I G H T S}

- Gypsum is a cement setting regulator, it is also a cement hydration accelerator.

- The use of gypsum at the optimum content, improves several cement properties.

- Its use below or above the optimum, affects adversely the cement properties.

- The optimum gypsum content is not fixed at $5 \%$, it varies from a cement to another.

- The optimum gypsum content depends mainly on: $\mathrm{SO}_{3} \%, \mathrm{C}_{3} \mathrm{~A} \%$, Alkali \% and cement SSB.

\section{A R T I C L E I N F O}

\section{Article history:}

Received 13 August 2017

Received in revised form 18 December 2017

Accepted 27 December 2017

\section{Keywords:}

Cement

Gypsum content

$\mathrm{SO}_{3}$

Optimum

Hydration

\section{G R A P H I C A L A B S T R A C T}

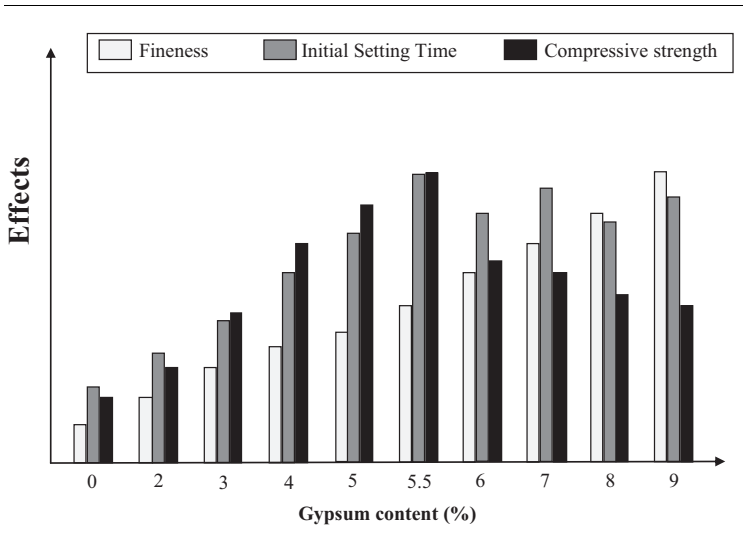

\begin{abstract}
A B S T R A C T
Portland cement CEM I is obtained from (95-97\%) of clinker and (3-5\%) of gypsum, according to EN 197-1 (2011) standard. Sulfur trioxide $\mathrm{SO}_{3}$ is the main component of gypsum (Calcium Sulfate Dihydrate $\mathrm{CaSO}_{4} \cdot 2 \mathrm{H}_{2} \mathrm{O}$ ), it may also originate from clinker, the previous standard has limited its content in cement at $4 \%$. It is known that the gypsum acts as a cement setting regulator, however, an appropriate gypsum quantity (optimum) may improve other properties such as: mechanical response, dimensional variations and hydration process. This optimum gypsum content is related to several parameters, namely: $\mathrm{SO}_{3} \%$, cement SSB (specific surface Blaine), $\mathrm{C}_{3} \mathrm{~A} \%$ and alkali \%. The aim of this work is to find, through an experimental protocol, the optimum gypsum content of an Algerian Portland cement CEM I. 10 variants containing various \% of gypsum were formulated, where properties of anhydrous cements, cement pastes and normalized cement mortars were studied. Results show that when gypsum is added below or above the optimum, water demand for normal consistency, setting times, compressive strength, heat of hydration, swelling, drying shrinkage and hydration degree were adversely affected. It has been experimentally demonstrated that this optimum gypsum content is $5.5 \%$ by weight.
\end{abstract}

(c) 2017 Elsevier Ltd. All rights reserved.

Cement chemistry abbreviations: $\mathrm{S}$, Silica, $\mathrm{SiO}_{2} ;$ A, Alumina, $\mathrm{Al}_{2} \mathrm{O}_{3} ; \mathrm{F}$, Ferric Oxide, $\mathrm{Fe}_{2} \mathrm{O}_{3} ; \mathrm{C}$, Calcium Oxide, $\mathrm{CaO} ; \overline{\mathrm{S}}$, Sulfur Trioxide, $\mathrm{SO}_{3} ; \mathrm{H}, \mathrm{Water}_{2} \mathrm{H}_{2} \mathrm{O} ; \mathrm{C}_{3} \mathrm{~S}, \mathrm{Tricalcium}$ Silicate, $3 \mathrm{CaO} \cdot \mathrm{SiO}_{2} ; \mathrm{C}_{2} \mathrm{~S}$, Dicalcium Silicate, $2 \mathrm{CaO} \cdot \mathrm{SiO}_{2} ; \mathrm{C}_{3} \mathrm{~A}$, Tricalcium Aluminate, $3 \mathrm{CaO} \cdot \mathrm{Al}_{2} \mathrm{O}_{3} ; \mathrm{C} \mathrm{C}_{4} \mathrm{AF}$, Tetracalcium Aluminoferrite, $4 \mathrm{CaO} \cdot \mathrm{Al}_{2} \mathrm{O}_{3} \cdot \mathrm{Fe}_{2} \mathrm{O}_{3} ; \mathrm{CS}_{2}, \mathrm{Gypsum}_{2}(\mathrm{calcium}$ sulfate dihydrate) $\mathrm{Ca}_{2} \mathrm{SO}_{4} 2 \mathrm{H}_{2} \mathrm{O}$; C-S-H, Calcium Silicate Hydrate, $\mathrm{CaO}-\mathrm{SiO}_{2}-\mathrm{H}_{2} \mathrm{O} ; \mathrm{CH}$, Calcium Hydroxide, $\mathrm{Ca}(\mathrm{OH})_{2} ; \mathrm{C}_{6} \mathrm{AS}_{3} \mathrm{H}_{32}, \mathrm{Ettringite}_{3} 3 \mathrm{CaO} \cdot \mathrm{Al}_{2} \mathrm{O}_{3} \cdot 3 \mathrm{CaSO} \mathrm{C}_{4} 32 \mathrm{H}_{2} \mathrm{O} ; \mathrm{C}_{4} \mathrm{AS}_{\bar{S}} \mathrm{H}_{12}$, Monosulfoaluminate, $3 \mathrm{CaO} \cdot \mathrm{Al}_{2} \mathrm{O}_{3} \cdot \mathrm{CaSO}_{4} 12 \mathrm{H}_{2} \mathrm{O}$.

* Corresponding author.

E-mail addresses: silinemohammed@univ-msila.dz (S. Mohammed), safiullah.omary@insa-strasbourg.fr (O. Safiullah). 


\section{Introduction}

The Portland cement CEM I is a powdery substance made from clinker and gypsum. Clinker is formed after firing a raw mill of limestone and clay at around $1450^{\circ} \mathrm{C}$, where chemical reactions take place to form essentially, calcium silicates $\left(C_{3} S, C_{2} S\right)$ and aluminates $\left(C_{3} A, C_{4} A F\right)$. Cement hydration is the chemical process that allows these minerals to react with water, giving rise to new cementitious compounds called hydration products, where the major phases are: calcium silicate hydrates (C-S-H) and calcium hydroxide $(\mathrm{CH})$. On complete hydration, $50-70 \%$ by weight of ordinary Portland cement is converted to $\mathrm{C}-\mathrm{S}-\mathrm{H}$ and up to $28 \%$, to $\mathrm{CH}$ [1]. Contrary to $\mathrm{CH}$ crystals that do not participate much in the matrix resistance, $\mathrm{C}-\mathrm{S}-\mathrm{H}$ is the main compound of cement bonding properties. This mineral with a low crystallinity degree, even amorphous, is formed from reactions of $C_{3} S$ and $C_{2} S$ with water according to reactions 1 and 2 .

$2 \mathrm{C}_{3} \mathrm{~S}+11 \mathrm{H} \rightarrow \mathrm{C}-\mathrm{S}-\mathrm{H}+3 \mathrm{CH}$

$2 \mathrm{C}_{2} \mathrm{~S}+9 \mathrm{H} \rightarrow \mathrm{C}-\mathrm{S}-\mathrm{H}+2 \mathrm{CH}$

The tricalcium aluminate $\left(C_{3} A\right)$ has a very high reactivity with water, which is the main cause of flash setting. Without gypsum in the binder, it can dissolve rapidly in water leading to an intermediate phases of hexagonal calcium aluminate hydrates $\left(\mathrm{C}_{2} \mathrm{AH}_{8}\right.$, $\mathrm{C}_{4} \mathrm{AH}_{19}$ and $\mathrm{C}_{4} \mathrm{AH}_{13}$ ) which turns into a more stable phase, Hydrogarnets $\mathrm{C}_{3} \mathrm{AH}_{6}$, according to reactions 3 and 4 .

$2 \mathrm{C}_{3} \mathrm{~A}+27 \mathrm{H} \rightarrow \mathrm{C}_{2} \mathrm{AH}_{8}+\mathrm{C}_{4} \mathrm{AH}_{19} \rightarrow 2 \mathrm{C}_{3} \mathrm{AH}_{6}+15 \mathrm{CH}$

$2 \mathrm{C}_{3} \mathrm{~A}+21 \mathrm{H} \rightarrow \mathrm{C}_{2} \mathrm{AH}_{8}+\mathrm{C}_{4} \mathrm{AH}_{13} \rightarrow 2 \mathrm{C}_{3} \mathrm{AH}_{6}+9 \mathrm{CH}$

Gypsum is an indispensable component in the cement manufacture, it's used mainly for regulating the setting time of cement. However, some of the mechanical properties of cement, namely strength, shrinkage and expansion in water may be affected by its level in the matrix [2]. Also, and in order to reduce the grinding energy required to produce cement, the gypsum is often added to the clinker upon its cooling and during the final grinding process in cement plants. Gypsum is a transparent or translucent sulfate mineral composed of calcium sulfate, found and mined, primarily from sedimentary deposits. Usual form of gypsum in nature is Dihydrate $\left(\mathrm{CaSO}_{4} \cdot 2 \mathrm{H}_{2} \mathrm{O}\right)$, more rarely Anhydrite $\left(\mathrm{CASO}_{4}\right)$, but Hemihydrate $\left(\mathrm{CaSO}_{4} \cdot 1 / 2 \mathrm{H}_{2} \mathrm{O}\right)$ is extremely unusual due to its unstable character.

To obtain cement, the sulfate source can be determinative. It is known that anhydrite dissolves very slowly in water, which affects the formation of ettringite and consequently, the resistance evolution, particularly at a very early age $[3,4]$. According to Agabgbou et al., [5], mechanical properties of cement pastes and mortars were more affected when hemihydrate is used, especially, in terms of dimensional variations where a greater drying shrinkage was found. In the field of cement industry, term of gypsum refers generally to calcium sulfate dihydrate $\left(\mathrm{CaSO}_{4} \cdot 2 \mathrm{H}_{2} \mathrm{O}\right)$. The gypsum content in cement is expressed in terms of its trioxide sulfate $\left(\mathrm{SO}_{3}\right)$ level. Portland cement contains usually around $5 \%$ of gypsum, but its level from $\mathrm{SO}_{3}$ must be less than $4 \%$, according to the European standard EN 197-1.

In the presence of water, gypsum reacts quickly with $\mathrm{C}_{3} \mathrm{~A}$ (Reaction (5)) to generate an Aft phase known as Ettringite $\left(\mathrm{C}_{6} \mathrm{AS}_{3} \mathrm{H}_{32}\right)$. The retardation mechanism of gypsum is forming these very fine grained crystals of ettringite, which develop a protective film on the cement particle surface to reject the movement of water [6] and delay the setting time of cement.

$\mathrm{C}_{3} \mathrm{~A}+3 \mathrm{C} \overline{\mathrm{S}} \mathrm{H}_{2}+26 \mathrm{H} \rightarrow \mathrm{C}_{6} \mathrm{AS}_{3} \mathrm{H}_{32}$
After exhaustion of gypsum, the residual $C_{3} A$ reacts with the formed ettringite giving rise to an AFm phase (calcium monosulfoaluminate) according to reaction 6 :

$2 \mathrm{C}_{3} \mathrm{~A}+\mathrm{C}_{6} \mathrm{AS}_{3} \mathrm{H}_{32}+4 \mathrm{H}_{2} \mathrm{O} \rightarrow 3 \mathrm{C}_{4} \mathrm{~A} \overline{\mathrm{S}} \mathrm{H}_{12}$

Similarly, the tetracalcium aluminoferrite $\left(\mathrm{C}_{4} \mathrm{AF}\right)$ reacts without (Reaction (7)) and with gypsum (Reactions (8) and (9)), but more slowly than $\mathrm{C}_{3} \mathrm{~A}$ and releasing a lower hydration heat.

$\mathrm{C}_{4} \mathrm{AF}+10 \mathrm{H} \rightarrow \mathrm{C}_{3} \mathrm{AH}_{6}+\mathrm{CH}+\mathrm{FH}_{3}$

$\mathrm{C}_{4} \mathrm{AF}+3 \mathrm{C} \overline{\mathrm{S}} \mathrm{H}_{2}+3 \mathrm{OH} \rightarrow \mathrm{C}_{6} \mathrm{AS}_{3} \mathrm{H}_{32}+\mathrm{CH}+\mathrm{FH}_{3}$

$2 \mathrm{C}_{4} \mathrm{AF}+\mathrm{C}_{6} \mathrm{AS}_{3} \mathrm{H}_{32}+12 \mathrm{H} \rightarrow 3 \mathrm{C}_{4} \mathrm{AS} \mathrm{S}_{12}+2 \mathrm{CH}+2 \mathrm{FH}_{3}$

The effect of gypsum on the hydration of $C_{3} S$ is widely studied by Menetrier et al., [7]. It has been demonstrated that the dissolution rate of $\mathrm{C}_{3} \mathrm{~S}$ increased in the presence of gypsum. Kurdowski [8], reported that the gypsum accelerates the $C_{3} S$ hydration mainly in the pre-induction period, its effect on cement hydration takes two aspects. It improves the amount and constitution of $\mathrm{C}-\mathrm{S}-\mathrm{H}$ gel, on the other hand, the C-S-H cohesiveness, being the function of $\mathrm{C} / \mathrm{S}$ ratio, is reduced.

In some recent studies, it appears that the authors have chosen arbitrarily the percentage of gypsum in the formulation of their cements. Although these percentages vary between 3 and 5, the $\mathrm{SO}_{3}$ content in gypsum varies from one research to another (Table 1). In cementitious system, a low gypsum content should not ensure sufficiently the retardation effect, while high gypsum level will affect considerably the cement strength and its dimensional stability. Moreover, the gypsum over dosage may have long term negative consequences that adversely affect the durability of cement concrete causing its serious damage.

Leklou et al. [14] reported that the Delayed Ettringite Formation (DEF) is a type of Internal Sulfate Attack (ISA) observed in cementitious materials and caused by heat-induced decomposition and/ or prevention of normal ettringite formed during the initial hydration of cement at elevated temperature (above about $70^{\circ} \mathrm{C}$ ) and its re-crystallization in the hardened matrix. This physico-chemical phenomenon induces an expansion of the cement paste and leads to cracks in concrete. These cracks result in a decrease of the mechanical performances and durability parameters of the material.

High content of gypsum in cement may be considered as one of the main causes of DEF. That's why and according to Paris et al. [15], limiting sulfate additions in cement is common to avoid DEF. The same authors noted that when excess soluble sulfates do not react completely, and when temperature reaches $70^{\circ} \mathrm{C}$, the DEF phenomenon occurs. In the set concrete, the unbound sulfates present in the microstructure react to form more voluminous chemical products, causing internal stresses in the concrete to build until cracks in the hardened concrete are formed, thus, compromising the structure. Furthermore, the high gypsum content favors the internal corrosion of concrete, particularly intensive for cements with high is $C_{3} A$ content and low fineness [8]. Therefore to limit this risk of expansion, especially in areas like Algeria where climatic conditions (high temperature, sun exposure and humidity) favor ettringite re-crystallization and DEF, it would be advantageous to avoid the use of cements with high sulfate contents.

In reality, there is an optimum \% of gypsum, which ensure for the matrix, a maximum strength and minimum shrinkage without excessive expansion in water [2,6]. According to Soroka and Abayneh [2], the gypsum content involves two opposing effects. Gypsum was shown to accelerate the cement hydration, particularly 
Table 1

Variation of the gypsum content in cement and that of the $\mathrm{SO}_{3}$ in gypsum, according to some references.

\begin{tabular}{|c|c|c|c|c|c|c|}
\hline \multirow[t]{2}{*}{ Reference } & \multirow[t]{2}{*}{ Gypsum \% (By weight of clinker) } & \multicolumn{3}{|c|}{$\mathrm{SO}_{3}$ content (\%) } & \multirow[t]{2}{*}{$\mathrm{C}_{3} \mathrm{~A}(\%)$} & \multirow[t]{2}{*}{$\mathrm{C}_{4} \mathrm{AF}(\%)$} \\
\hline & & In Clinker & In Gypsum & In Cement & & \\
\hline Assaad Joseph Jean [9] & 5 & 0.22 & 43.1 & 1 & 9.47 & 13.08 \\
\hline Naceri and Hamina [10] & 5 & 0.54 & 27.83 & & 11.2 & 8.2 \\
\hline Hamidi et al. [11] & 4.8 & 1 & 1 & 3.4 & 8.7 & 8.1 \\
\hline Hamidi et al. [11] & 4.5 & I & 1 & 4.8 & 7.4 & 11.2 \\
\hline Ghiasvand et al. [12] & 4 & 0.75 & 28.1 & 1 & 7.49 & 8.98 \\
\hline Yilmaz and Ediz [13] & 3.5 & 1.21 & 46.12 & 1 & 7.4 & 11.72 \\
\hline Hamidi et al. [11] & 3 & 1 & 1 & 2.2 & 10.4 & 6.9 \\
\hline
\end{tabular}

at the early ages up to 3 days, which improves the strength at an early age. As for the adverse effect, the formation of excessive amounts of ettringite, and the possible internal cracking, may be considered as a possible explanation when the $\mathrm{SO}_{3}$ content exceeds a certain threshold (Optimum). This optimum depends on the $\mathrm{SO}_{3}$ content in gypsum, but also on the amounts of $\mathrm{SO}_{3}, \mathrm{C}_{3} \mathrm{~A}$ and $\mathrm{C}_{4} \mathrm{AF}$ in the clinker, \% of alkali in raw materials and the cement fineness. The literature contains several analytical formulas allowing to calculate this optimal content of $\mathrm{SO}_{3}$ as a function of all these parameters. According to Kurdowski [8], the \% of $\mathrm{SO}_{3 \text { (Optimum) }}$ can be calculated by one of these formulas:

$$
\begin{aligned}
\% \mathrm{SO}_{3 \text { (Optimum })=} & 0.556 \mathrm{Na}_{2} \mathrm{O}_{2}+0.0017659 \mathrm{SSB} \\
& +0.1072 \mathrm{Fe}_{2} \mathrm{O}_{3}-3.6004 \\
\% \mathrm{SO}_{3 \text { (Optimum })}= & 0.093 \mathrm{Al}_{2} \mathrm{O}_{3}+1.71 \mathrm{Na}_{2} \mathrm{O}_{2}+0.94 \mathrm{~K}_{2} \mathrm{O}+1.23 \\
\% \mathrm{SO}_{3 \text { (Optimum })}= & 6.810^{-5} \mathrm{SSB}_{3} \mathrm{~A} \\
\% \mathrm{SO}_{3 \text { (Optimum })}= & 1.841+0.095 \mathrm{C}_{3} \mathrm{~A}+1.6364 \mathrm{Na}_{2} \mathrm{O}_{2}
\end{aligned}
$$

However, ASTM C563-07 standard proposed an approximation to calculate the \% of $\mathrm{SO}_{3 \text { (Optimum) }}$ based on the compressive strength:

$$
\% \mathrm{SO}_{3(\text { Optimum })}=[a /(a-b)] c+\mathrm{d}+(c / 2)
$$

Where:

a: average strength both rounds of Mixture $\mathrm{N}^{\circ} 2$ minus Mixture $\mathrm{N}^{\mathrm{o}} 1$.

$b$ : average strength both rounds of Mixture $\mathrm{N}^{\circ} 3$ minus Mixture $\mathrm{N}^{\mathrm{o}} 2$.

c: $\left(\% \mathrm{SO}_{3}\right.$ in gypsum) $/ 100$, and $d=\% \mathrm{SO}_{3}$ in test cement.

The aim of this paper is to find experimentally this $\mathrm{SO}_{3 \text { (Optimum) }}$ for an Algerian Portland cement CEM I.

\section{Materials and methods}

\subsection{Clinker and gypsum}

The used clinker was an ordinary Portland cement clinker, it was provided by Lafarge cement company of M'sila in Algeria. It was crushed with a ball mill until a fineness of $3270 \mathrm{~cm}^{2} / \mathrm{g}$. In terms of mineralogical composition, the clinker contains $66.43 \%$ of $C_{3} S, 11.55 \%$ of $C_{2} S, 6.24 \%$ of $C_{3} A$ and $12.08 \%$ of $C_{4} A F$. Moreover, the chemical analysis (Table. 2) shows its conformity with the requirements specified in EN 197-1 standard, as the mass ratio $(\mathrm{CaO}) /\left(\mathrm{SiO}_{2}\right)$ is greater than 2.0 and moreover, the content of $\mathrm{MgO}$ is less than $5.0 \%$ by weight.

The gypsum (Calcium sulfate dihydrate $\mathrm{CaSO}_{4} \cdot 2 \mathrm{H}_{2} \mathrm{O}$ ) was provided from the same cement plant. Its Blaine fineness and density were $4680 \mathrm{~cm}^{2} / \mathrm{g}$ and $2.52 \mathrm{~g} / \mathrm{cm}^{3}$, respectively. The gypsum chemical composition is summarized in Table 2.

In this study, a total of 10 variants of cement were prepared, in which levels of $0 \%, 2 \%, 3 \%, 4 \%, 5 \%, 5.5 \%, 6 \%, 7 \%, 8 \%$, and $9 \%$ respectively, of the clinker weight were substituted by gypsum. To obtain these cements, the materials, clinker and gypsum, were separately grounded in a laboratory ball mill, then, sieved, mixed and homogenized according to the selected cement formulations.

\subsection{Anhydrous cements}

The chemical compositions of cement variants were determined by X-ray fluorescence (XRF) according to NF P15-467, the conformity of obtaining cement results was deemed with the EN 197-1 standard. Furthermore, anhydrous cements were subject to specific gravity and Blaine specific surface tests by using of NF P 94-054 and NF EN 196-6 respectively, where each recorded result was the average value of three successive measures.

\subsection{Cement pastes}

Cement pastes containing $500 \mathrm{~g}$ from each one of the cements, with different ratios of $w / c$, were subjected to normal consistency and setting time tests, according to NF EN 196-3. The aim was to pull the influence of gypsum amounts on water-cement ratios $(w / c)$ in each paste, needed for obtaining normalized consistency, characterized by a distance of $6 \pm 1 \mathrm{~mm}$ between the plunger and the base-plate of Vicat apparatus. As gypsum is mainly used as a cement setting regulator, the setting time test was carried out in order to appreciate this material effect on cements initial and final setting times, measured by a numerical Vicat apparatus for the same pastes.

\subsection{Mortars}

The cements were used in the confection of mortar specimens

\begin{tabular}{|c|c|c|c|c|c|c|c|c|c|c|c|}
\hline & $\mathrm{SiO}_{2}$ & $\mathrm{Al}_{2} \mathrm{O}_{3}$ & $\mathrm{Fe}_{2} \mathrm{O}_{3}$ & $\mathrm{CaO}$ & $\mathrm{MgO}$ & $\mathrm{SO}_{3}$ & $\mathrm{~K}_{2} \mathrm{O}$ & $\mathrm{Na}_{2} \mathrm{O}$ & LOI & $\mathrm{SSB}\left(\mathrm{cm}^{2} / \mathrm{g}\right)$ & $\rho\left(\mathrm{cm}^{3} / \mathrm{g}\right)$ \\
\hline Clinker & 21.5 & 4.89 & 3.97 & 65.92 & 1.59 & 0.73 & 0.69 & 0.10 & 0.3 & 3270 & 3.17 \\
\hline Gypsum & 3.37 & 0.82 & 0.32 & 32.19 & 4.20 & 37.52 & 0.15 & 0 & 26.86 & 4680 & 2.52 \\
\hline
\end{tabular}
$\left(4 * 4 * 16 \mathrm{~cm}^{3}\right)$ by using normalized sand, with a cement-sand weight ratio $(S / C)$ of $1 / 3$ according to the NF EN 196-1 standard, the $w / c$ ratio was 0.5 . In the fresh state, the hydration heat of

Table 2

Chemical compositions (\%) and physical properties of clinker and gypsum. 
mortars after $41 \mathrm{~h}$ was measured by isothermal calorimeter, according to NF EN 196-9. The hardened specimens were subjected to tests of compressive strength, swelling and shrinkage in accordance with NF EN 196-1 and NF P-15-433 standards respectively. The compressive strengths were determined using a $3 \mathrm{R}$ press with a loading speed of $2400( \pm 200) \mathrm{N} / \mathrm{s}$. For each mixture and hydration time, the compressive strength was the average of six test results. Dimensional variations were determined on $4 * 4 * 16 \mathrm{~cm}$ specimens, formulated with each cement variant according to NF EN 196- 1 and cured at 3 and 28 days. For the swelling test, specimens were placed in water bath $\left(20 \pm 2{ }^{\circ} \mathrm{C}\right)$, while for the draying shrinkage one, specimens were kept in a curing chamber at $20^{\circ} \mathrm{C}$ and $50 \%$ relative humidity. The retained value for each test was the average of three results.

The thermogravimetric analysis (TGA) was carried out by a LABSYS EVO STA 1600 device, it used to assess the hydration degree of cured samples in water at 3 and 28 days, which presents the ratio of chemically bound water of cement paste at a given time, to that of fully hydrated paste [16]. At the testing times, a 50 to $200 \mathrm{mg}$ taken from specimens of each mortar variant, broken in the compressive strength test, was grounded then placed into the crucible device. The TGA tests were performed under a dynamic heating ramp up to $1000^{\circ} \mathrm{C}$ with a heating rate of $10^{\circ} \mathrm{C} / \mathrm{min}$. During the test, the cement hydrates are decomposed and the relative mass losses are recorded on TGA curves. Three main phases summarize these decompositions (Fig. 1): the dehydration of hydrates $\mathrm{C}-\mathrm{S}-\mathrm{H}, \mathrm{C}_{2} \mathrm{ASH}_{8}, \mathrm{C}_{4} \mathrm{AH}_{13}$ and $\mathrm{C}_{3} \mathrm{AH}_{6}$ $\left(105-400{ }^{\circ} \mathrm{C}\right)$, the Portlandite dehydroxylation $\left(400-600{ }^{\circ} \mathrm{C}\right)$ and the carbonates decarbonation $\left(600-900{ }^{\circ} \mathrm{C}\right)$ [17-19]. However, the main difficulty of this technique is to determine the border temperature between free and chemically bound water which varies from one author to another between 105 [16] and 145 ${ }^{\circ} \mathrm{C}[18,20]$.

In this paper, the hydration degree is calculated using the modified method of Bhatty $[18,20]$ in which, the hydration degree $\alpha(\%)$ is given at time $t$ by the following formula:

$\alpha(t)=\frac{W_{c}(t)}{W_{100} \times m_{c}}$

Where:

- $W_{c}$ : Mass losses due to the chemically bound water at time $\mathrm{t}$, measured by TGA curves (\%):

$W_{c}=\left(\Delta_{145-1000^{\circ} \mathrm{C}}\right)-\left(\Delta_{600-800^{\circ} \mathrm{C}}\right)+\left(d_{145-1000^{\circ} \mathrm{C}}\right)-m_{c} \times L O I$
Where:

- $\left(d_{145-1000^{\circ} \mathrm{C}}\right)$ : The mass change of empty crucible between 145 and $1000{ }^{\circ} \mathrm{C}$ (Device's drift).

- $m_{C}$ : Mass of cement included in the sample $(\mathrm{g})$ :

$m_{c}=\frac{m_{\text {sample }}}{\left(1+\frac{W}{C}\right)(1+L O I)}$

- $W_{100}$ : The proportion of water mass required for complete (100\%) cement hydration, calculated with the Bogue formula ( $\mathrm{g} / \mathrm{g}$ of cement):

$\mathrm{W}_{100}=0.24\left(\mathrm{C}_{3} \mathrm{~S}\right)+0.21\left(\mathrm{C}_{2} \mathrm{~S}\right)+0.4\left(\mathrm{C}_{3} \mathrm{~A}\right)+0.37\left(\mathrm{C}_{4} \mathrm{AF}\right)$.

\section{Results and discussion}

\subsection{Anhydrous cements}

\subsubsection{Chemical analysis}

Table 3 shows the chemical compositions of cements as a function of their gypsum content. These results indicate the cements conformity with the chemical requirements of EN 197-1, as the LOI, \% of $\mathrm{Cl}$ and \% of $\mathrm{SO}_{3}$ were less than $5 \%, 0.1 \%$ and $4 \%$, respectively, except for variant with $9 \%$ of gypsum were the $\mathrm{SO}_{3}$ content was $4.03 \%$.

The addition of gypsum caused an absolute increase in LOI and $\mathrm{SO}_{3}$ content in cements, contrary to their contents from $\mathrm{CaO}, \mathrm{SiO}_{2}$, $\mathrm{Al}_{2} \mathrm{O}_{3}$ and $\mathrm{Fe}_{2} \mathrm{O}_{3}$ which decreased with the gypsum content increase. Furthermore, $\mathrm{Na}_{2} \mathrm{O}$ and $\mathrm{K}_{2} \mathrm{O} \%$ are not influenced by the gypsum content in cements, which have a beneficial effect in reducing the expansion of mortar and concrete caused by the alkali-silica reaction. The effect of gypsum content on $\mathrm{MgO} \%$ in cements is not obvious, though results of Table 2 indicate that free $\mathrm{MgO} \%$ in gypsum is $4.2 \%$. Thus, more investigations through resistance and swelling tests are required.

\subsubsection{Cements specific gravity and Blaine fineness}

The effect of gypsum content on specific gravity and SSB of cements is graphically plotted in Figs. 2 and 3 respectively. It seems that the obtained results were influenced by the gypsum physical properties. The decrease in cements specific gravities is mainly due to the difference between densities of clinker $\left(3.17 \mathrm{~g} / \mathrm{cm}^{3}\right)$ and gypsum $\left(2.52 \mathrm{~g} / \mathrm{cm}^{3}\right)$. However, the incorporation of gypsum, which is finer than clinker $\left(4680\right.$ to $3270 \mathrm{~cm}^{2} / \mathrm{g}$ ) had

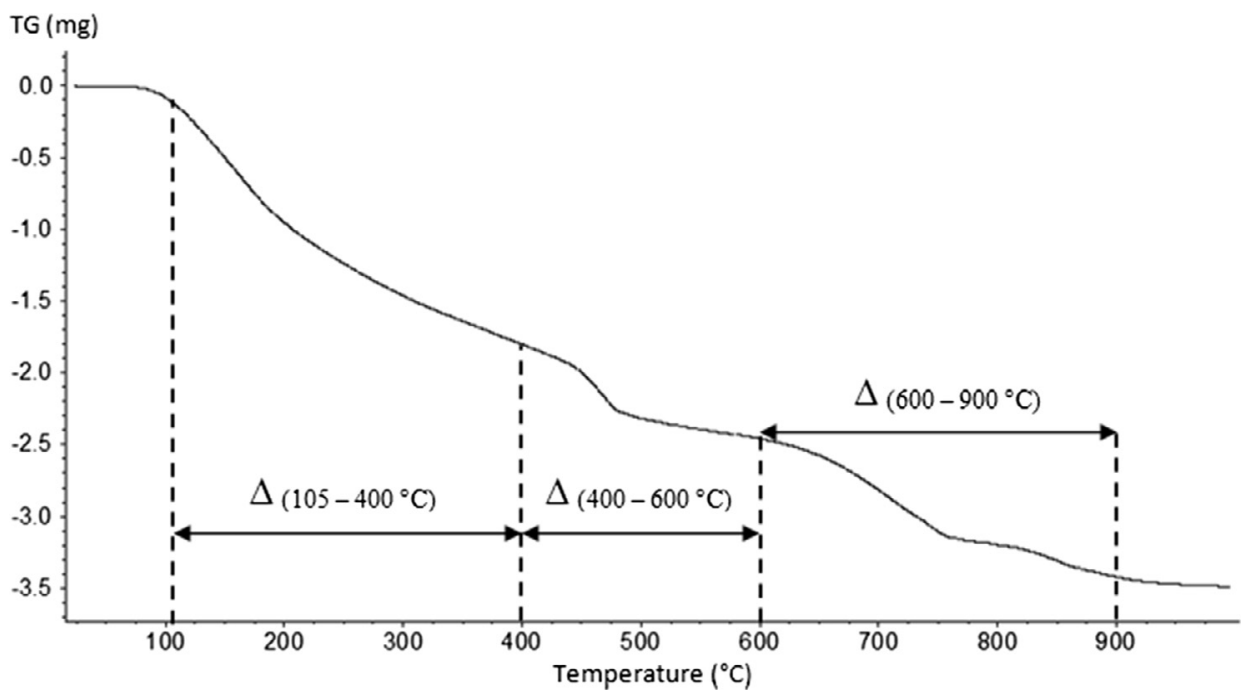

Fig. 1. Main decomposition phases of cement paste under the temperature effect between 105 and $1000{ }^{\circ} \mathrm{C}$ by TGA 
Table 3

Chemical analysis (\%) of studied cements.

\begin{tabular}{|c|c|c|c|c|c|c|c|c|c|c|}
\hline Gypsum content (\%) & $\mathrm{SiO}_{2}$ & $\mathrm{Al}_{2} \mathrm{O}_{3}$ & $\mathrm{Fe}_{2} \mathrm{O}_{3}$ & $\mathrm{CaO}$ & $\mathrm{MgO}$ & $\mathrm{SO}_{3}$ & $\mathrm{Cl}$ & $\mathrm{K}_{2} \mathrm{O}$ & $\mathrm{Na}_{2} \mathrm{O}$ & LOI \\
\hline 0 (Clinker) & 21.5 & 4.89 & 3.97 & 65.92 & 1.59 & 0.73 & 0.02 & 0.69 & 0.1 & 0.3 \\
\hline 2 & 19.86 & 4.96 & 3.41 & 63.97 & 1.53 & 1.53 & 0.02 & 0.57 & 0.1 & 0.8 \\
\hline 3 & 20.06 & 4.63 & 3.28 & 63.94 & 1.54 & 2.04 & 0.03 & 0.58 & 0.11 & 0.85 \\
\hline 4 & 19.96 & 4.76 & 2.96 & 61.37 & 1.54 & 2.52 & 0.02 & 0.59 & 0.11 & 1.12 \\
\hline 5 & 19.95 & 4.72 & 2.98 & 61.86 & 1.55 & 2.78 & 0.02 & 0.6 & 0.12 & 1.44 \\
\hline 5.5 & 19.86 & 4.71 & 3.13 & 59.42 & 1.56 & 3.02 & 0.03 & 0.61 & 0.12 & 1.42 \\
\hline 6 & 19.46 & 4.73 & 3.18 & 60.47 & 1.57 & 3.22 & 0.01 & 0.61 & 0.11 & 1.74 \\
\hline 7 & 19.19 & 4.79 & 3.27 & 59 & 1.58 & 3.48 & 0.03 & 0.62 & 0.12 & 2.1 \\
\hline 8 & 19.31 & 4.74 & 3.25 & 58.7 & 1.61 & 3.78 & 0.01 & 0.63 & 0.11 & 2.39 \\
\hline 9 & 19.03 & 4.54 & 3.07 & 58.75 & 1.6 & 4.03 & 0.01 & 0.64 & 0.11 & 2.4 \\
\hline
\end{tabular}

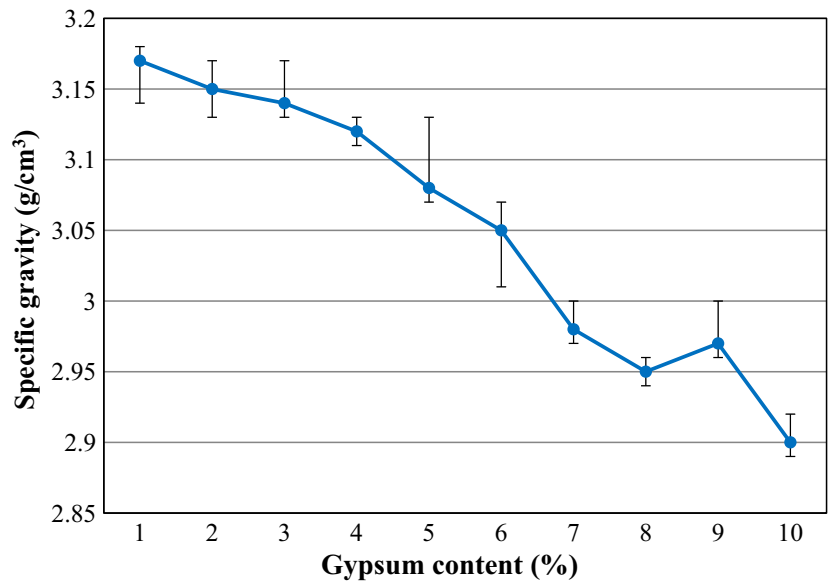

Fig. 2. Effect of gypsum content on the Specific Gravity of studied cements.

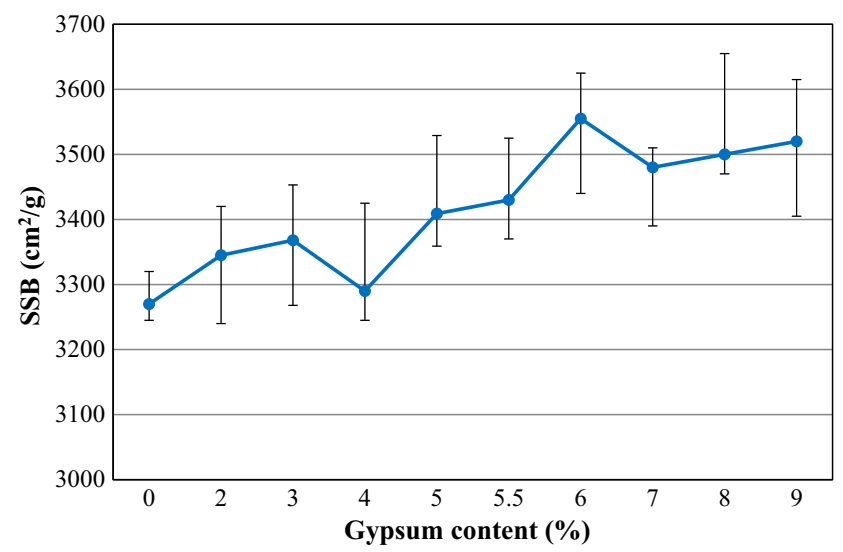

Fig. 3. Effect of gypsum content on the Blaine fineness of studied cements.

increased the cement fineness. Except variants with $4 \%$ and $6 \%$, cements SSB were in an absolute increase as a function of their gypsum content. It should be noted that theoretical values, obtained from the mixture law, show a great agreement with those experimental one, which present a sign of the homogeneity of cement mixtures.

\subsection{Cement pastes}

\subsubsection{Water demand for normal consistency}

The evolution of the water-to-cement ratio for normal consistency as a function of the gypsum content is represented in Fig. 4. As can be seen from these results, the water demand increased with the increase of gypsum content in cements. It increased from $122 \mathrm{~g}$,

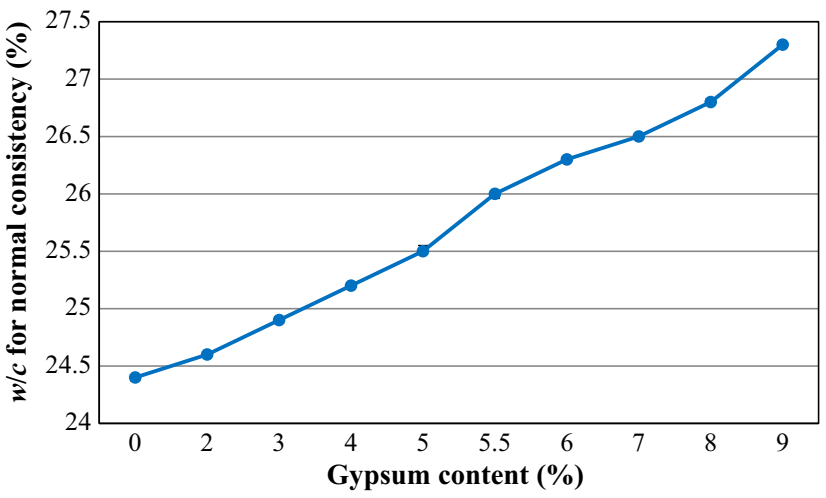

Fig. 4. Effect of gypsum content on the $w / c$ ratio, required for normal consistency.

recorded for variant without gypsum, to $130 \mathrm{~g}$ and $136.5 \mathrm{~g}$ for those containing $5.5 \%$ and $9 \%$ of gypsum respectively, which is equivalent to $6.56 \%$ and $11.88 \%$ of growth, respectively. The increase of water requirement can be attributed to two main factors: cements fineness [12] and hydration process [20].

As reported by Schiller and Ellerbrock [21], the water demand is divided in three main parts: the most large fraction is needed to lubricate the surfaces of the cement grains, a lower fraction to form the initial hydration products, and another one to lubricate these hydration products. That's what we can deduce from the hydration process presented above. In the presence of gypsum, the formation of hydrates ettringite and calcium monosulfoaluminate from $\mathrm{C}_{3} \mathrm{~A}$ and $\mathrm{C}_{4} \mathrm{AF}$ (Reactions 3, 4 and 7), requires more quantity of water compared to that of other hydrates $\left(\mathrm{C}_{2} \mathrm{AH}_{8}, \mathrm{C}_{4} \mathrm{AH}_{19}, \mathrm{C}_{4} \mathrm{AH}_{13}\right.$ and $\mathrm{C}_{3} \mathrm{AH}_{6}$ ), formed in the absence of gypsum (Reactions 5, 6, 8 and 9). The increase in gypsum content leads logically to increase in water demand.

On the other hand, and as seen from Fig. 3, cements fineness increased with their gypsum content. The fineness expresses the surface to be surrounded by water molecules, the increase in fineness leads to a larger wetting surface, hence a higher $w / c$ ratio. Similar findings have been reported by other researchers [12,22].

\subsubsection{Setting time}

It is well known that the onset of significant C-S-H formation is the main cause of cement setting, the mechanism that governs the transition from plastic phase to hardened one is characterized by an increase in the system's viscosity. It is true that the cement setting time depends to the $w / c$ ratio $[23,24]$ and the cement fineness [25], but the $\mathrm{SO}_{3}$ content remains more efficient. The effect of gypsum content on setting time of cements is presented in Fig. 5. It is obvious from results that gypsum had delayed the cement initial and final set when used up to $5.5 \%$, beyond this content, the increase in gypsum, remains insignificant with regard to the setting times. Compared to cement without gypsum, the cement with 


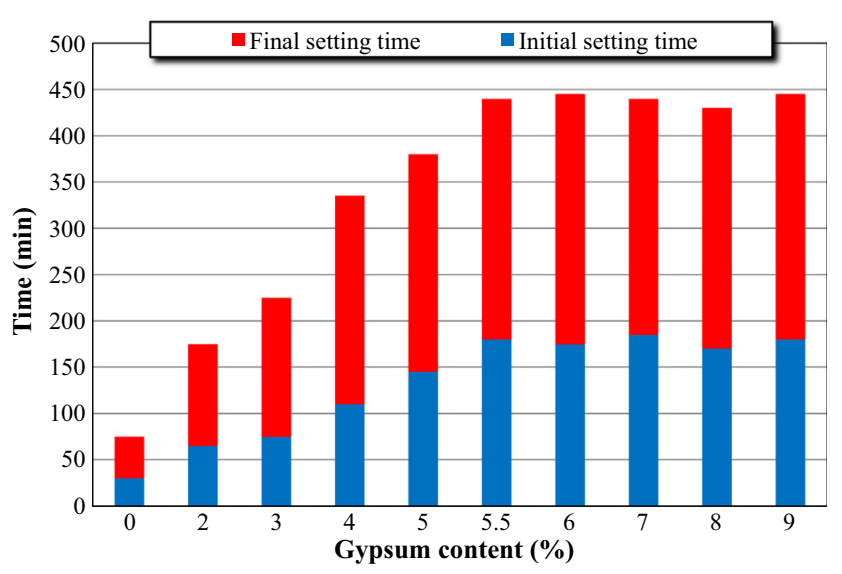

Fig. 5. Effect of gypsum content on setting times.

$5.5 \%$ of gypsum required an additional time of $150 \mathrm{mn}$, for its initial set, and $215 \mathrm{mn}$, for its final one. Whereas, the retardation was $+35 \mathrm{mn}$ and $+65 \mathrm{mn}$ for initial and final set, respectively, in the case of cement with $2 \%$ of gypsum.

The shorter setting times of cements with 0,2 and $3 \%$ of gypsum are mainly attributed to the high $\mathrm{C}_{3} \mathrm{~A}$ level without sufficient gypsum. That means, with less than $2 \%$ of $\mathrm{SO}_{3}$ in cements, low amount of ettringite $\left(\mathrm{C}_{6} \mathrm{AS}_{3} \mathrm{H}_{32}\right)$ is formed, which is insufficient to regularize the setting. Beyond 5.5\% of gypsum, the setting time remains approximately constant and the gypsum becomes overdose. Although the setting time does not seem to be affected by the high gypsum contents, it should be noted that the gypsum excess have a long term negative effect, since it may lead to delayed ettringite formation (DEF). Thus, limiting the gypsum content at $5.5 \%$ is required to avoid this phenomenon.

In view of these results, it can be concluded that the optimum of gypsum content for this cement is $5.5 \%$ ( $3 \%$ of $\mathrm{SO}_{3}$ ). It must be noted that the EN 197-1 limit the initial setting time at $45 \mathrm{mn}$ for CEM 52.5 and $60 \mathrm{mn}$ for CEM 42.5, therefore, all studied cements satisfied this requirement except that without gypsum. Similar findings are reported by other researches [6,26].

\subsection{Mortars}

\subsubsection{Heat of hydration}

The formation of hydration products is a complex mechanism of exothermic reactions leading to a heat release. Table 4 represents the hydration heat evolved from different cements at $41 \mathrm{~h}$. It must be pointed that the NF EN 197-1/A1 (2004) standard limits the hydration heat of low heat Portland cements after $41 \mathrm{~h}$ at $300 \mathrm{~J} / \mathrm{g}$. The results indicate that the highest heat release is obtained for cement without gypsum $(315 \mathrm{~J} / \mathrm{g}$ ) and cements manufactured with $8 \%(320 \mathrm{~J} / \mathrm{g})$ and $9 \%(367 \mathrm{~J} / \mathrm{g}$ ) of gypsum, while the variant containing $5.5 \%$ of gypsum released the lowest hydration heat quantity with $235 \mathrm{~J} / \mathrm{g}$.

As the released hydration heat depends on the cements component reactions such us $\mathrm{C}_{3} \mathrm{~S}, \mathrm{C}_{2} \mathrm{~S}, \mathrm{C}_{3} \mathrm{~A}, \mathrm{C}_{4} \mathrm{AF}$ and free lime, the gypsum content was probably the main cause of these findings. It is known that without gypsum, the $C_{3} A$ release the highest hydration heat $(\approx 1300 \mathrm{~J} / \mathrm{g}$ ), which justifies the result found for the variant containing $0 \%$ of gypsum. The higher the gypsum content, the lower the heat released decreases, up to a gypsum content of
5.5\%. This is attributed to the delaying effect of gypsum on the $\mathrm{C}_{3} \mathrm{~A}$ and $\mathrm{C}_{4} \mathrm{AF}$ reactions. Beyond $5.5 \%$ of gypsum, the hydration heat increases due to the excessive formation of Brucite and Portlandite from gypsum that not used in ordinary hydration of cement components described in reactions 5 and 8 . It should be noted that this formation can have a negative effects on performances of mortar, especially compressive strength and swelling. It can be concluded that the optimum gypsum content is $5.5 \%$, because the high values of hydration heat cause cracking and increase the thermal shrinkage of hardened mortars and concretes [27] and the improvement of durability means according to Hossain et al., [28] reduced heat of hydration.

\subsubsection{Compressive strength}

The effect of gypsum content on compressive strengths of normalized mortar specimens $\left(4^{*} 4^{*} 16 \mathrm{~cm}\right)$ is shown in Fig. 6. As expected, the compressive strength increased with age, the rate of increase depended upon the gypsum content and age. The results show that the compressive strength increases with the increasing gypsum content at all ages up to 5.5\% of gypsum content. Above this content, the compressive strength increases with age and decreases with increasing gypsum content. Compared to variant without gypsum which recorded the lowest strengths at all ages, that one containing 5.5\% of gypsum exhibited the highest strength values at 2,7 and 28 days with increasing rates of $127.17 \%, 86.5 \%$ and $61.08 \%$ respectively.

It is known that the gypsum improves the dissolution of alite and belite [7] and accelerates their hydration [2,8] giving $\mathrm{C}-\mathrm{S}-\mathrm{H}$ and Portlandite according to reactions 1 and 2. Besides, gypsum had a beneficial effect on the formed C-S-H amount [8]. As the compressive strength depends on the resulted hydration products, mainly C-S-H [29], results of Fig. 6 can be attributed to the presence of gypsum, but also, to its level. It seems that gypsum favored a better production of hydrates generators of bonding properties which led to increase in compressive strength with increase in gypsum content up to $5.5 \%$. The decrease of resistance beyond the level of $5.5 \%$ from gypsum confirms that there is an optimum content above which the strength gradually decreases.

As reported by Menetrier et al., [7], in the presence of gypsum, the rate of $\mathrm{C}_{3} \mathrm{~S}$ dissolution increases especially at early age, therefore, the precipitation of hydration products will be improved. Soroka and Abayneh [2] established that it accelerates the rate of cement hydration when added below its optimum. They added that the use of an appropriate content of gypsum improves the quality of C-S-H, while excess gypsum results in an inferior gel with a higher $\mathrm{C} / \mathrm{S}$ ratio, which decreases the compressive strength. In a recent study [26], where the authors varied the gypsum content between 2 and $6 \%$, the optimum corresponding to maximum compressive strengths at 3 and 28 days was $4 \%$. It should be highlighted that, as a function of gypsum content, the increase in 2 days compressive strength corresponds to a decrease in hydration heat at $41 \mathrm{~h}$, up to $5.5 \%$, beyond which, the trends reverse. As shown in Fig. 7 , resistance is negatively correlated with heat of hydration, the gypsum content of $5.5 \%$ seems optimum because it led to maximum strength and minimal heat of hydration.

\subsubsection{Swelling}

The swelling of mortar specimens made with the cement variants and placed in water bath $\left(20 \pm 2{ }^{\circ} \mathrm{C}\right)$, at 3 and 28 days, as a function of gypsum content is illustrated in Fig. 8. The swelling

Table 4

Effect of gypsum content on the hydration heat.

\begin{tabular}{|c|c|c|c|c|c|c|c|c|c|c|}
\hline Gypsum content & $0 \%$ & $2 \%$ & $3 \%$ & $4 \%$ & $5 \%$ & $5.5 \%$ & $6 \%$ & $7 \%$ & $8 \%$ & $9 \%$ \\
\hline Heat of hydration $(\mathrm{J} / \mathrm{g})$ & 315 & 274 & 257 & 243 & 239 & 235 & 241 & 281 & 320 & 367 \\
\hline
\end{tabular}




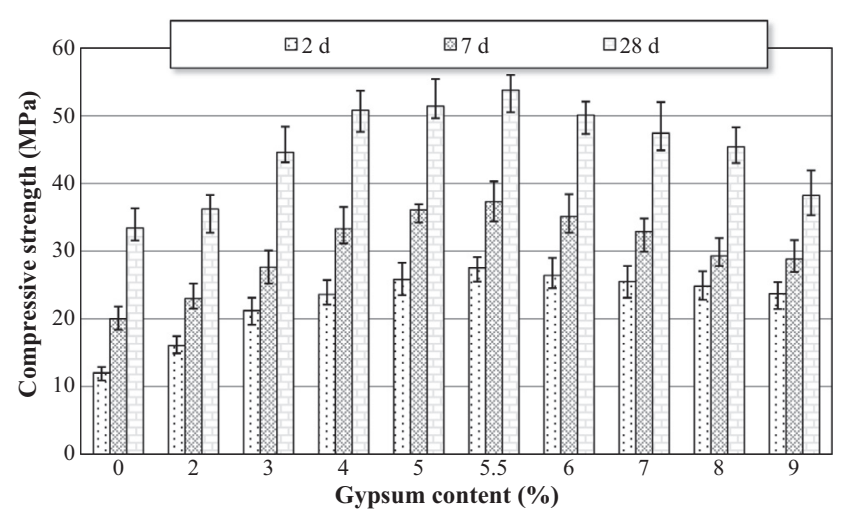

Fig. 6. Effect of gypsum content on compressive strength.

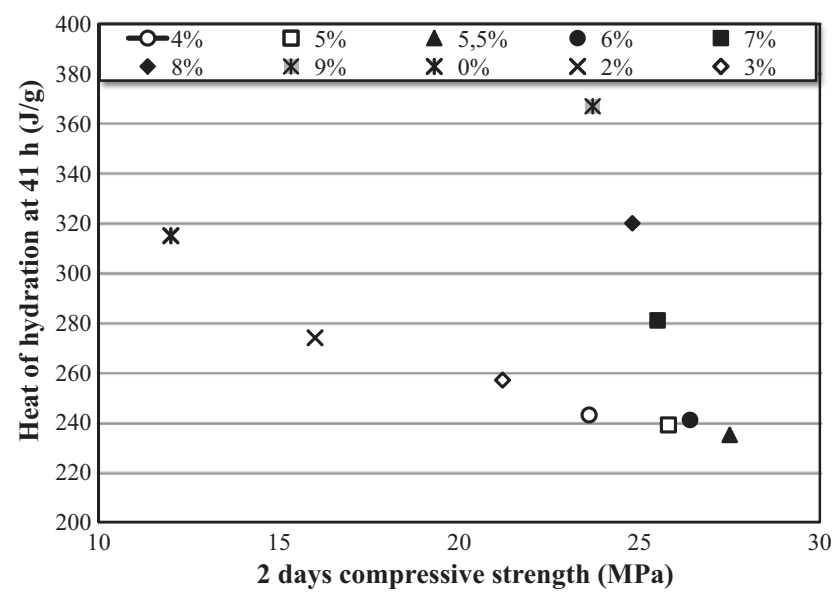

Fig. 7. Correlation between compressive strength and heat of hydration.

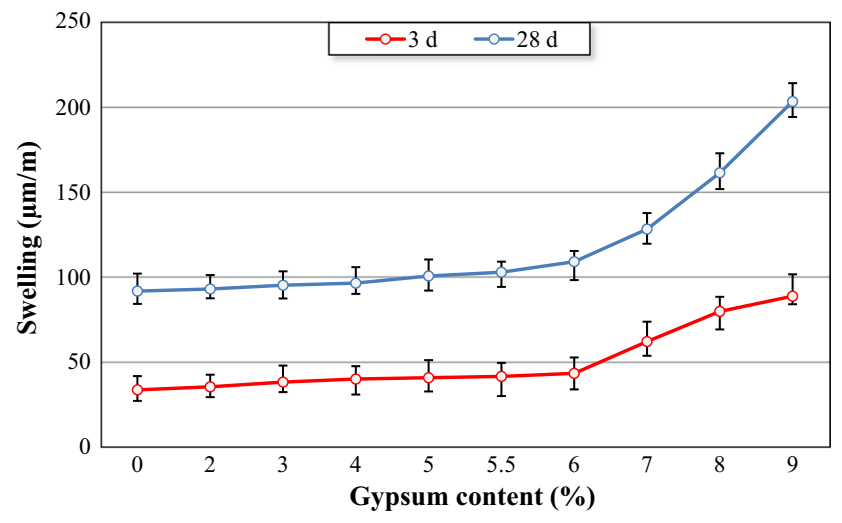

Fig. 8. Effect of gypsum content on swelling of mortars.

increases with curing period and gypsum content. Variant without gypsum presented the lowest swelling at both ages, while variant with $9 \%$ of gypsum content recorded the highest one. Growing rates were not the same, between 0 and 6\% of gypsum content, the swelling is slightly increased, but above to $6 \%$ of gypsum content, the increasing rate is higher. For example, at the age of 28 days, the swelling of sample with $6 \%$ of gypsum was $18.94 \%$ greater than that of comparable mortar without added gypsum, whereas the swelling of that one containing $9 \%$ of gypsum was 1.22 times over.

It is clearly obvious that the gypsum content is the main cause of these swelling results, especially when gypsum is used above its optimum content. According to Kurdowski [8], the optimum gypsum content should react completely and at early age with $C_{3} A$ to form ettringite, while the high content of gypsum content causes a risk of mortar swelling. The main cause of this swelling according to Soroka and Abayneh [2] is the continued formation of ettringite in the set cement. The authors established that, for cements with high gypsum content, a topochemical reaction occurs between residual gypsum and $\mathrm{C}_{3} \mathrm{~A}$ at later stages (more than $48 \mathrm{~h}$ ), to form excessive amounts of ettringite which may lead to sulfate expansion.

It should be pointed that the unreacted gypsum, used in the present study, contains significant amounts of free $\mathrm{CaO}$ and $\mathrm{MgO}$ (Table 2). Brucite and Portlandite thus formed have a high swelling potential which may be at the origin of results found for the overdose gypsum variants. Similar findings were reported by other authors $[2,30,31]$.

\subsubsection{Drying shrinkage}

Samples of mortar, made with the different cements, were kept in a curing chamber at $20{ }^{\circ} \mathrm{C}$ and $50 \%$ relative humidity in order to evaluate their drying shrinkage at 3 and 28 days, the results are plotted in Fig. 9. As the $\mathrm{SO}_{3}$ content is known by its reducer effect of shrinkage $[2,8,32]$, the obtained results are mainly attributed to the gypsum content in samples.

At the age of 3 days, sample without gypsum showed a high drying shrinkage $(234.61 \mu \mathrm{m} / \mathrm{m})$. This is probably due to its low hydration, which is in agreement with its low compressive strength (Fig. 6) and its high release of hydration heat (Table 4). For this variant, it appears that the fast hydration of $\mathrm{C}_{3} \mathrm{~A}$, main cause of the high value recorded for hydration heat, prevented the hydration of all $C_{3} S$ and $C_{2} S$, which led to a low compressive strength at early age. The hydration water of this mortar was not well consumed, so, its evaporation under the drying conditions was the main cause of the recorded shrinkage.

For other variants, the gypsum content had two contradictory effects. It led to a decrease in drying shrinkage when added at 3\% (for measurements taken at 3 days) and 6\% (for measurements taken at 28 days). Above these contents, the gypsum caused, again, an increase in the drying shrinkage. For the first case, the variants are apparently well hydrated, which is in accordance with results of hydration heat and compressive strength, while for the second, it seems that the gypsum surplus was unfavorable. It should be noted that the NF P 15-301 standard, limits the drying shrinkage after 28 days at $1000 \mu \mathrm{m} / \mathrm{m}$.

\subsubsection{Degree of hydration}

The hydration degrees of different samples, calculated using Eq. (6) at 3 and 28 days of curing, are given in Table 5 and Fig. 10. As

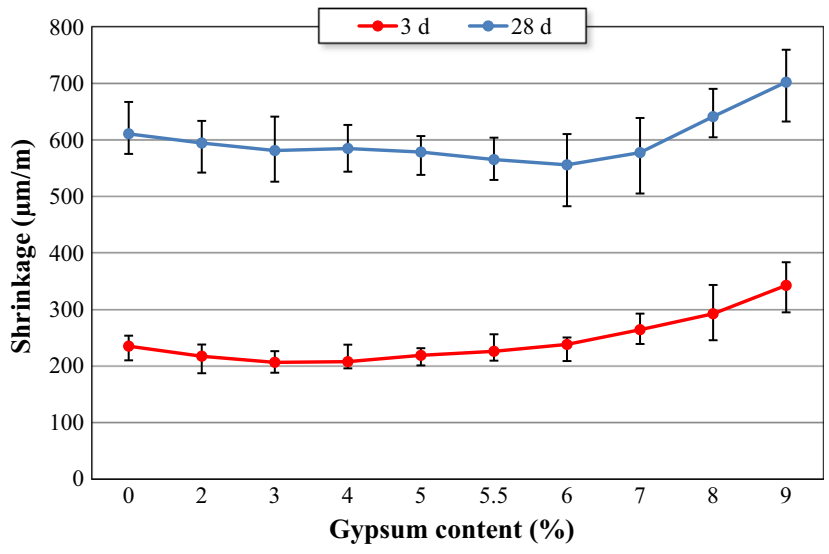

Fig. 9. Effect of gypsum content on drying shrinkage of mortars. 
Table 5

Samples hydration degrees at 3 and 28 days.

\begin{tabular}{|c|c|c|c|c|c|c|c|}
\hline Gypsum content (\%) & $\mathrm{m}_{\text {sample }}(\mathrm{mg})$ & $\mathrm{m}_{\mathrm{c}}(\mathrm{mg})$ & $\mathrm{W}_{100}$ & $\Delta_{\left(145-1000^{\circ} \mathrm{C}\right)}(\mathrm{mg})$ & $\Delta_{\left(600-800^{\circ} \mathrm{C}\right)}(\mathrm{mg})$ & $\mathrm{W}_{\mathrm{c}}(\mathrm{mg})$ & $\alpha(\%)$ \\
\hline $0(3 d)$ & 56.101 & 37.289 & 0.228 & 3.125 & 0.937 & 2.116 & 25 \\
\hline $0(28 d)$ & 189.171 & 125.737 & 0.228 & 14.774 & 3.424 & 11.013 & 38 \\
\hline $2(3 d)$ & 163.81 & 108.34 & 0.216 & 10.074 & 2.926 & 6.332 & 27 \\
\hline $2(28 d)$ & 145.392 & 96.159 & 0.216 & 11.442 & 2.486 & 8.227 & 40 \\
\hline $3(3 d)$ & 128.804 & 85.146 & 0.216 & 9.093 & 2.421 & 5.988 & 33 \\
\hline $3(28 d)$ & 162.996 & 107.748 & 0.216 & 15.012 & 2.901 & 11.235 & 48 \\
\hline $4(3 d)$ & 132.541 & 87.382 & 0.204 & 9.172 & 2.24 & 5.993 & 34 \\
\hline $4(28 d)$ & 109.249 & 72.026 & 0.204 & 12.902 & 2.174 & 9.961 & 68 \\
\hline $5(3 d)$ & 111.365 & 73.189 & 0.206 & 9.310 & 2.461 & 5.835 & 39 \\
\hline $5(28 d)$ & 98.634 & 64.822 & 0.206 & 10.485 & 2.032 & 7.56 & 57 \\
\hline $5.5(3 d)$ & 153.201 & 100.704 & 0.2 & 13.037 & 3.094 & 8.553 & 42 \\
\hline $5.5(28 d)$ & 134.068 & 88.127 & 0.2 & 14.935 & 3.191 & 10.53 & 60 \\
\hline $6(3 d)$ & 171.056 & 112.087 & 0.204 & 14.54 & 3.438 & 9.191 & 40 \\
\hline $6(28 d)$ & 134.456 & 88.104 & 0.204 & 14.911 & 3.079 & 10.34 & 58 \\
\hline $7(3 d)$ & 110.22 & 71.969 & 0.199 & 9.534 & 2.689 & 5.373 & 38 \\
\hline 7 (28d) & 135.144 & 88.243 & 0.199 & 14.906 & 3.392 & 9.701 & 55 \\
\hline $8(3 d)$ & 132.623 & 86.351 & 0.198 & 11.724 & 3.66 & 6.04 & 35 \\
\hline $8(28 d)$ & 107.428 & 69.947 & 0.198 & 11.108 & 2.782 & 6.694 & 48 \\
\hline $9(3 d)$ & 134.695 & 87.692 & 0.198 & 12.621 & 4.499 & 6.057 & 35 \\
\hline $9(28 d)$ & 141.428 & 92.075 & 0.198 & 15.656 & 5.417 & 8.07 & 44 \\
\hline
\end{tabular}

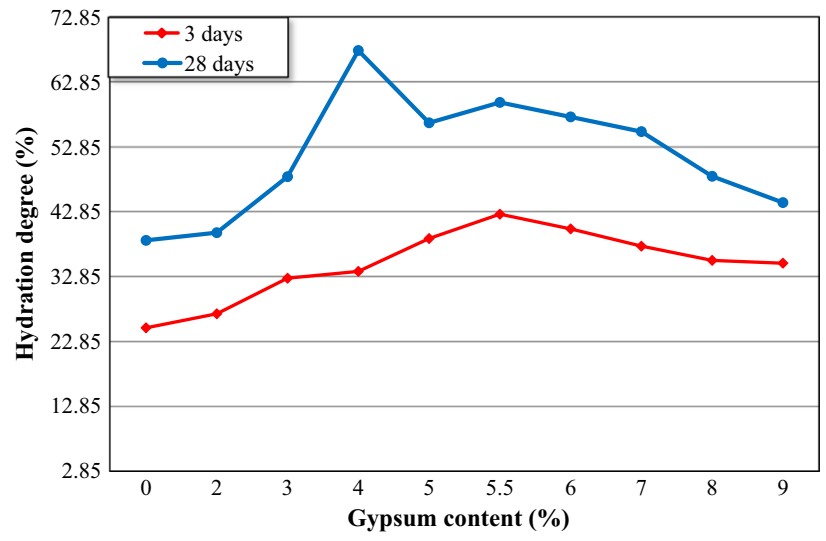

Fig. 10. Effect of gypsum content on hydration degree.

expected, the degree of hydration increased with age, but it also depended on the gypsum content in cements. At 3 days, variant without gypsum gave the lowest degree of hydration (24.89\%). The low amount of chemically bound water in this variant, means that it has formed little quantity of hydration products, which is at the origin of its low compressive strength at 2 days (12 MPa), its high hydration heat $(315 \mathrm{~J} / \mathrm{g})$ and shrinkage $(234.61 \mu \mathrm{m} / \mathrm{m})$. However, with $5.5 \%$ of gypsum, the 3-days hydration degree was
(42.46\%), which was beneficial in terms of resistance at 2 days (25.8 MPa). The increase of gypsum content, more than $5.5 \%$, led to a decrease in the hydration degree. At 28 days, it appears that $4 \%$ is the optimum content of gypsum, the hydration degree decreases below and above this content value.

As gypsum accelerates the $C_{3} S$ hydration [8,33], the increase in degree of hydration can be attributed to the gypsum beneficial effect. Without gypsum and when gypsum is used below to its optimum, the dissolution of the anhydrous components $\left(C_{3} S\right.$ and $\mathrm{C}_{2} \mathrm{~S}$ ) is slow due to fast hydration of $\mathrm{C}_{3} \mathrm{~A}$, therefore, the formation of hydration products (mainly $\mathrm{C}-\mathrm{S}-\mathrm{H}$ and $\mathrm{CH}$ ) is prevented, which leads to a low hydration degree. The use of gypsum with content exceeding the range of $5.5 \%$ at 3 days and $4 \%$ at 28 days, significantly retarded the cements hydration [2], which decreased their hydration degrees.

\section{Conclusion}

The effect of gypsum content on properties of anhydrous cements, cement pastes and mortars was studied using various contents of gypsum. The main conclusions that can be drawn from this study are:

- Physical properties of cement are affected by the gypsum content, the higher the gypsum \%, the higher the fineness, the more

Table 6

Optimum gypsum content.

\begin{tabular}{|c|c|c|c|}
\hline & Studied properties & Optimum gypsum \% & Optimum $\mathrm{SO}_{3}$ content in cement \\
\hline Anhydrous cements & $\begin{array}{l}\text { Chemical composition } \\
\text { SSB } \\
\text { Density }\end{array}$ & $\begin{array}{l}\text { From } 2 \text { to } 8 \% \\
\text { Not obvious } \\
\text { Not obvious }\end{array}$ & $\begin{array}{l}1.53 \% \text { to } 3.78 \% \\
\text { Not obvious } \\
\text { Not obvious }\end{array}$ \\
\hline Cement pastes & $\begin{array}{l}\text { Normal consistency } \\
\text { Setting time }\end{array}$ & $\begin{array}{l}\text { Not obvious } \\
\text { From } 4 \text { to } 9 \%\end{array}$ & $\begin{array}{l}\text { Not obvious } \\
2.52 \% \text { to } 4.03 \%\end{array}$ \\
\hline Cement mortars & $\begin{array}{l}\text { Heat of hydration } \\
\text { Compressive strength } \\
\text { Swelling } \\
\text { Drying shrinkage } \\
\text { Degree of hydration }\end{array}$ & $\begin{array}{l}\text { From } 2 \text { to } 7 \% \\
5.5 \% \\
\text { From } 2 \text { to } 6 \% \\
\text { From } 3 \text { to } 6 \% \\
4 \text { and } 5.5 \%\end{array}$ & $\begin{array}{l}1.53 \% \text { to } 3.48 \% \\
3.02 \% \\
1.53 \% \text { to } 3.22 \% \\
2.04 \% \text { to } 3.22 \% \\
2.52 \% \text { and } 3.02 \%\end{array}$ \\
\hline Theoretical formulas & $\begin{array}{l}\text { Formula (1) } \\
\text { Formula (2) } \\
\text { Formula (3) } \\
\text { Formula (4) }\end{array}$ & & $\begin{array}{l}1.81 \% \\
2.51 \% \\
1.39 \% \\
2.6 \%\end{array}$ \\
\hline
\end{tabular}


the decrease in cement density. Similarly, the influence of gypsum content on chemical compositions was obvious, especially in terms of $\mathrm{CaO}, \mathrm{SO}_{3}, \mathrm{SiO}_{2}$ and $\mathrm{LOI}$. Except for variant with $9 \%$ of gypsum, all cements were in accordance with the requirements stated in EN 197-1.

- When gypsum is used in cement pastes, water demand for normal consistency increased obviously with the increase of gypsum content. At the same time, gypsum has a significant delaying effect, with the increase of its content, setting times increased up to the optimum gypsum \% (5.5\%). When the gypsum \% exceeds the optimum, setting times remains not influenced.

- The gypsum optimum was more obvious from compressive strengths results. The mortar containing 5.5\% of gypsum recorded the highest values at 2,7 and 28 days. When gypsum is more or less than the optimum, strengths are gradually reduced. The addition of $5.5 \%$ of gypsum led to low values of hydration heat, swelling and drying shrinkage.

- As the gypsum has a beneficial effect on cement hydration, the optimum gypsum \%, that ensure higher hydration degree was $5.5 \%$ at 3 days and $4 \%$ at 28 days.

- The gypsum content that ensured the highest strength and the lowest heat of hydration was $5.5 \%$. Furthermore, this content led to high hydration degree and produced only low values of swelling and drying shrinkage. Thus, and according to results of this study (Table. 6), the optimum of gypsum content for the studied cement is $5.5 \%$ (3.02\% of $\mathrm{SO}_{3}$ ).

\section{References}

[1] B.B. Sabir, S. Wild, J. Bai, Metakaolin and calcined clays as pozzolans for concrete: a review, Cem. Concr. Compos. 23 (2001) 441-454.

[2] I. Soroka, M. Abayneh, Effect of gypsum on properties and internal structure of PC paste, Cem. Constr. Res. 16 (1986) 495-504.

[3] M. García-Maté, A.G. De La Torre, L. León-Reina, E.R. Losilla, M.A.G. Aranda, I. Santacruz, Effect of calcium sulfate source on the hydration of calcium sulfoaluminate eco-cement, Cem. Concr. Compos. 55 (2015) 53-61.

[4] G. Tzouvalas, N. Dermatas, S. Tsimas, Alternative calcium sulfate-bearing materials as cement retarders Part I. Anhydrite, Cem. Concr. Res. 34 (2004) 2113-2118.

[5] A. Mardani-Aghabaglou, O.C. Boyaci, H. Hosseinnezhad, B. Felekoğlu, K. Ramyar, Effect of gypsum type on properties of cementitious materials containing high range water reducing admixture, Cem. Concr. Compos. 68 (2016) 15-26.

[6] F. Liu, M.Z. Lan, Effects of gypsum on cementitious systems with different mineral mixtures, Key Eng. Mater. 509 (2012) 20-25.

[7] D. Ménétrier, I. Jawed, J. Skalny, Effect of gypsum on $C_{3} S$ hydration, Cem. Concr. Res. 10 (1980) 697-701.

[8] Kurdowski W. Chapter 4: Cement Hydration. Cement and Concrete Chemistry 2014, 205-277, Doi: 10.1007/978-94-007-7945-7.

[9] Joseph J. Assaad, Quantifying the effect of clinker grinding aids under laboratory conditions, Mater. Eng. 81 (2015) 40-51.

[10] A. Naceri, M.C. Hamina, Use of waste brick as a partial replacement of cement in mortar, Waste Manage. (Oxford) 29 (2009) 2378-2384.
[11] M. Hamidi, L. Kacimi, M. Cyr, P. Clastres, Evaluation and improvement of pozzolanic activity of andesite for its use in eco-efficient cement, Constr. Build. Mater. 47 (2013) 1268-1277.

[12] E. Ghiasvand, A.A. Ramezanianpour, A.M. Ramezanianpour, Effect of grinding method and particle size distribution on the properties of Portland-pozzolan cement, Constr. Build. Mater. 53 (2014) 547-554.

[13] B. Yilmaz, N. Ediz, The use of raw and calcined diatomite in cement production, Cem. Concr. Compos. 30 (2008) 202-211.

[14] N. Leklou, Nguyen, P. Mounanga, The effect of the partial cement substitution with fly ash on delayed ettringite formation in heat-cured mortars, KSCE J. Civ. Eng. 21 (2017) 1359-1366.

[15] J.M. Paris, J.G. Roessler, C.C. Ferraro, H.D. DeFord, T.G. Townsend, A review of waste products utilized as supplements to Portland cement in concrete, J. Cleaner Prod. 121 (2016) 1-18.

[16] J.I. Bhatty, Hydration versus strength in a Portland cement developed from domestic mineral wastes-a comparative study, Thermochim. Acta 106 (1986) 93-103.

[17] A. Sepulcre Aguilar, J. Pinilla Melo, Olivares F. Hernandez, Microstructura analysis of aerated cement pastes with fly ash, metakaolin and sepiolite additions, Constr. Build. Mater. 47 (2013) 282-292.

[18] W. Deboucha, N. Leklou, A. Khelidj, M.N. Oudjit, Hydration development of mineral additives blended cement using thermogravimetric analysis (TGA): methodology of calculating the degree of hydration, Constr. Build. Mater. 146 (2017) 687-701.

[19] M. Siline, E. Ghorbel, M. Bibi, Effect of freeze-thaw cycles on the physicomechanical properties of a pozzolanic mortar, Constr. Build. Mater. 134 (2017) 32-38.

[20] P. Mounanga, Experimental Study of the Behavior of Cement Pastes at Very Young Age: Hydration, Shrinkage, Thermophysical Properties Doctoral Thesis, University of Nantes, France, 2003.

[21] B. Schiller, H.G. Ellerbrock, The grinding and properties of cement with several main constituents, Zement-Kalk-Gips 45 (7) (1992) 325-334.

[22] A.O. Mashaly, B.A. El-Kaliouby, B.N. Shalaby, A.M. El-Gohary, M.A. Rashwan, Effects of marble sludge incorporation on the properties of cement composites and concrete paving blocks, J. Cleaner Prod. 112 (2016) 731-741.

[23] A. Çolak, Characteristics of pastes from a Portland cement containing different amounts of natural pozzolan, Cem. Concr. Res. 33 (2003) 585-593.

[24] J.J. Brooks, M.A. Megat Johari, M. Mazloom, Effect of admixture on the setting times of high strength concrete, Cem. Concr. Compos. 22 (2000) 293-301.

[25] N. Dave, A.K. Misra, A. Srivastava, S.K. Kaushik, Setting time and standard consistency of quaternary binders: The influence of cementitious material addition and mixing, Int. J. Sust. Built Environ. 6 (2017) 30-36.

[26] Y. Yao, D.W. Yang, H.X. Tong, J.L. Zeng, Y. Liu, Modification of waste fluorgypsum and its applications as a cement retarder, J. Central South Univ. Technol. 18 (2011) 1402-1407.

[27] R. Talero, Expansive Synergic Effect of ettringite from pozzolan (metakaolin) and from OPC, co-precipitating in a common plaster-bearing solution: Part I: by cement pastes and mortars, Constr. Build. Mater. 24 (2010) 1779-1789.

[28] M.M. Hossain, M.R. Karim, M. Hasan, M.K. Hossain, M.F.M. Zain, Durability of mortar and concrete made up of pozzolans as a partial replacement of cement: a review, Constr. Build. Mater. 116 (2016) 128-140.

[29] A. Tironi, M.A. Trezza, A.N. Scian, E.F. Irassar, Assessment of pozzolanic activity of different calcined clays, Cem. Concr. Compos. 37 (2013) 319-327.

[30] Y. Qing, C. Huxing, W. Yuqing, W. Shangxian, L. Zonghan, Effect of MgO and gypsum content on long-term expansion of low heat Portland slag cement with slight expansion, Cem. Concr. Compos. 26 (2004) 331-337.

[31] D. Torréns-Martin, L. Fernandez-Carrasco, Effect of sulfate content on cement mixtures, Constr. Build. Mater. 48 (2013) 144-150.

[32] E.F. Irassar, D. Violini, V.F. Rahhal, C. Milanesi, M.A. Trezza, V.L. Bonavetti, Influence of limestone content, gypsum content and fineness on early age properties of Portland limestone cement produced by inter-grinding, Cem. Concr. Compos. 33 (2011) 192-200.

[33] Y. Zhang, X. Zhang, Research on effect of limestone and gypsum on $C_{3} A, C_{3} S$ and PC clinker system, Constr. Build. Mater. 22 (2008) 1634-1642. 